\title{
Instruments used to evaluate functional health literacy in elderly persons with chronic kidney disease: Integrative review
}

Monique de Freitas Gonçalves Lima' (D)

Eliane Maria Ribeiro de Vasconcelos' ID Anna Karla de Oliveira Tito Borba' ${ }^{1}$

\section{Abstract}

Objective: To identify the instruments used to evaluate the functional health literacy of elderly persons with chronic kidney disease, and to assess whether they are suitable for this population. Method: An integrative review of the Lilacs, PubMed, Ibecs, Scopus and Cochrane databases was carried out in July and August 2018, seeking original articles dealing with functional health literacy and chronic kidney disease in the elderly. Results: A total of 15 articles were evaluated and seven different instruments used in the research were identified, with the Rapid Estimate of Adult Literacy in Medicine (REALM) Keywords: Elderly. Health and Test of Functional Health Literacy in Adults (TOFHLA) the most prevalent. Conclusion: The instruments identified are applicable for the elderly, but are not specific for this population. The construction and/or adaptation of new instruments is suggested considering the specific characteristics of this age group.

Universidade Federal de Pernambuco (UFPE), Centro de Ciências da Saúde, Programa de Pós-Graduação em Gerontologia (PPGERO). Recife, Pernambuco, Brasil. 


\section{INTRODUCTION}

Functional Literacy in Health (FHL) implies the knowledge, motivation and competence of an individual to access, understand, evaluate and apply health information to judge and make decisions in daily life about health care, disease prevention and health promotion, to maintain or improve their quality of life ${ }^{1}$.

The World Health Organization (WHO), through its Commission on Social Determinants of Health, has identified FHL as one such determinant, as it can contribute to improving the ability of an individual to access, understand, evaluate and communicate information so that they can improve their health, as well as that of their family and the community ${ }^{2}$.

The Brazilian population is aging rapidly, with the elderly vulnerable to low FHL as a consequence of their biological conditions and social vulnerability ${ }^{3}$. In Brazil, $49 \%$ of the population is considered functionally illiterate ${ }^{4}$. In addition, there is a potential for a large portion of this population to develop a chronic disease, requiring suitable health control and the development of individual skills to better address risks and self-care strategies. Actions that promote improvements in the literacy of the population and the evaluation of FHL can therefore be a contributing factor to delaying the onset of these diseases ${ }^{5}$.

During the aging process the elderly face challenges in their self-management of day-to-day activities following the manifestation of chronic diseases (CD). They struggle to control symptoms, comply with treatment regimens, minimize the negative consequences of their physical decline, and change their lifestyle to deal with the limitations created by the disease. It is estimated that patients with low FHL have difficulties in administering $\mathrm{CDs}$, demonstrating inadequate self-management and eventually experiencing poor health outcomes ${ }^{6}$.

Chronic Kidney Disease (CKD) is highly prevalent among the elderly, who are particularly susceptible to a reduction in renal function due to the physiological decline of glomerular filtration due to aging? In addition, cognitive impairment is common in individuals with CKD undergoing hemodialysis, which hampers adherence to treatment ${ }^{8}$.
Cognitive impairment often occurs in CKD. The conditions most associated with these losses are depression, delirium, mild cognitive impairment, and depression. The mechanisms involved are yet to be established, but factors such as uremic toxininduced injury, ischemic cerebrovascular injury, oxidative stress, chronic inflammation, anemia, hyperhomocysteinemia, and endothelial dysfunction may be important ${ }^{9}$.

Within this context, it is common for individuals to receive information about their condition that include unknown medical terminologies, such as laboratory results and even the clinical behaviors they will undergo. This information requires basic reading and numeracy skills so that the individual can actually understand their meaning ${ }^{10}$.

Due to its importance, studies on literacy in health and the resources to measure it have been carried out. Tests validated so far allow the degree of literacy in health of individuals and populations to be assessed and, thus, the most appropriate intervention to be determined in cases where there are limitations of the skills evaluated. This process is fundamental for achieving more favorable patient outcomes ${ }^{11}$.

The problem of such studies occurs from the moment in which cognitive loss occurs in the aging process, which is more pronounced in elderly persons with CKD and which has a direct impact on the performance in FHL tests. In addition, a low level of literacy can interfere with the understanding of elderly persons in relation to CKD and negatively affect possible health education actions, due to the lack of knowledge of health professionals when measuring literacy levels through individualized actions. In an attempt to contribute to the broadening of knowledge regarding health actions, the present study aimed to identify the instruments used to evaluate the FHL of the elderly with CKD, as well as assess whether they are adequate for this population.

\section{METHODS}

An integrative literature review was carried out, as this method of study enables the synthesis of knowledge of a given subject, as well as identifying gaps which should be filled by new studies ${ }^{12}$. In 
order to carry out this review, the following steps were taken: establishing of the guiding question; selection of articles and inclusion criteria; evaluation of included studies; interpretation of results, and presentation of the integrative review. In order to guide the research, the following question was elaborated: What instruments are used for the evaluation of FHL in elderly persons with CKD and are they adequate for this public?

Data collection took place in July and August 2018 and the following databases were used for the selection of articles: PubMed, Lilac, Ibecs, Cochrane and Scopus. The MeSH (Medical Subject Headings) and DECs (Health Sciences Descriptors) descriptors Aged/healthliteracy/Renal insufficiency were used in English as this would identify the greatest numbers of articles, and were combined with the use of the Boolean operator AND. There were no limitations on the date of publication of the studies due to the incipience of research on the subject.

Also in this stage, the titles and abstracts were carefully read in order to verify compliance with the following inclusion criteria: articles that used instruments to measure health literacy and included elderly people in the results. The exclusion criterion were articles that did not address health literacy in the title or abstract, which were discarded, along as those that did not mention the instruments and results of the evaluation of health literacy, articles repeated on search platforms (used only once), reviews, and articles that did not address renal insufficiency within the context of literacy.

To evaluate the quality of the selected studies, two instruments were used: the first, the Critical Apprenticeship Skills Program (Casp) ${ }^{13}$, a critical reading skills program, part of the Public Health Resource Unit (PHRU). The instrument is composed of ten items (maximum 10 points), covering: 1) objective; 2) methodological adequacy; 3) presentation of theoretical and methodological procedures; 4) sample selection; 5) procedure for data collection; 6) relationship between researcher and those surveyed; 7) consideration of ethical aspects; 8) procedure for data analysis; 9) presentation of results; 10) importance of research. The studies were classified based on the following scores: 6 to 10 points (good methodological quality and reduced bias), with a minimum of 5 points (satisfactory methodological quality, but with increased risk of bias). In this study, we chose to use only articles classified from 6 to 10 points.

The second instrument was the Hierarchical Classification of Evidence for the Evaluation of Studies, and included the following levels: 1) systematic review or meta-analysis; 2) randomized clinical trials; 3) non-randomized clinical trial; 4) cohort and case-control studies; 5) systematic review of descriptive and qualitative studies; 6) descriptive or qualitative study; 7) authoritative opinion and/ or report of committee of experts ${ }^{14}$. At the end of the analysis of these two instruments, 15 articles remained.

A descriptive analysis of the distribution of the following variables was performed: order of articles, method and level of evidence, objective, instrument used and results. All the variables were critically analyzed and discussed. The main characteristics of the selected studies and of the most frequently occurring instruments for the evaluation of health literacy were organized in charts and tables.

\section{RESULTS}

Table 1 shows the results obtained in the descriptor-based search by database.

Certain articles were excluded as they did not include an FHL instrument or were repeated in more than one database, as in the case of Scopus (04), and were computed only once.

Articles from 2009 to 2017 were found, with the largest number identified in the PubMed database, and no other articles found in other databases. An average of two publications per year was observed, while the country with the greatest number of publications was the USA (Chart 1).

Eight of the studies were cross-sectional in design, four were cohort studies, two were randomized and one was a methodological study. One article had an evidence level of VII, eight a level of VI, four a level of IV and two were level II. 
Table 1. Distribution of articles found and selected by database. Recife, Pernambuco, 2018.

\begin{tabular}{lllll}
\hline Database & \multicolumn{3}{c}{ Articles } \\
\cline { 2 - 5 } & Found & Pre-Selected & Excluded & Selected \\
\hline Pubmed & 60 & 24 & 9 & 15 \\
Cochrane & 4 & 2 & 2 & 0 \\
Scopus & 25 & 4 & 4 & 0 \\
Lilacs & 1 & 0 & 0 & 0 \\
Ibecs & 1 & 0 & 0 & 0 \\
Total & 91 & 30 & 15 & 15 \\
\hline
\end{tabular}

Chart 1. Synthesis of selected studies for the analysis of health literacy assessment instruments $(n=15)$. Recife, Pernambuco, 2018.

\begin{tabular}{|c|c|c|c|c|}
\hline $\begin{array}{l}\text { Title, authors, country } \\
\text { and year of publication }\end{array}$ & $\begin{array}{l}\text { Method/level of } \\
\text { evidence }\end{array}$ & Instrument used & Objective & Results \\
\hline $\begin{array}{l}\text { Functional health } \\
\text { literacy and knowledge } \\
\text { of renal patients on } \\
\text { pre-dialytic treatment. } \\
\text { Moraes KL, Brasil VV, } \\
\text { Oliveira GF, Cordeiro } \\
\text { JABL, Silva AMTC, } \\
\text { Boaventura RP, et al. } \\
\text { Brazil, } 2017\end{array}$ & $\begin{array}{l}\text { Cross-sectional/ } \\
\text { VI }\end{array}$ & $\begin{array}{l}\text { Brief test of health } \\
\text { literacy in adults } \\
\text { (BTOFHLA) }\end{array}$ & $\begin{array}{l}\text { To analyze FHL* } \\
\text { and knowledge about } \\
\text { chronic kidney disease } \\
\text { in patients undergoing } \\
\text { pre-dialysis treatment. }\end{array}$ & $\begin{array}{l}\text { The average age of the } \\
\text { interviewees was } 63 \\
\text { (30-90) years, and the } \\
\text { test was not limited } \\
\text { by age. All presented } \\
\text { inadequate health } \\
\text { literacy. }\end{array}$ \\
\hline $\begin{array}{l}\text { Limited health literacy in } \\
\text { advanced kidney disease } \\
\text { Dominic M. Taylor et al } \\
\text { UK, } 2016 \text {. }\end{array}$ & $\begin{array}{l}\text { Multi-center, } \\
\text { prospective cohort } \\
\text { / IV }\end{array}$ & $\begin{array}{l}\text { Single-Item } \\
\text { Literacy Screener } \\
\text { (SILS) }\end{array}$ & $\begin{array}{l}\text { To determine } \\
\text { the prevalence of } \\
\text { limited FHL and } \\
\text { its associations } \\
\text { with demographics, } \\
\text { comorbidity, and } \\
\text { socioeconomic } \\
\text { status in patients } \\
\text { at three different } \\
\text { stages of treatment: } \\
\text { early dialysis, kidney } \\
\text { transplant waiting } \\
\text { list, and kidney } \\
\text { transplantation. }\end{array}$ & $\begin{array}{l}\text { The age of patients } \\
\text { in the study with } \\
\text { advanced kidney } \\
\text { disease ranged from } 18 \\
\text { to } 75 \text { years. FHL was } \\
\text { limited as defined by } \\
\text { SILS. }\end{array}$ \\
\hline $\begin{array}{l}\text { Development of a health } \\
\text { literacy questionnaire for } \\
\text { Taiwanese hemodialysis } \\
\text { patients. Chung-liang } \\
\text { Shih, Tuan-hsun Chang, } \\
\text { Dana A. Jensen and } \\
\text { Chiung-hsuan Chiu. } \\
\text { Taiwan, 2016. }\end{array}$ & Methodology & $\begin{array}{l}\text { Health literacy } \\
\text { questionnaire } \\
\text { for Taiwanese } \\
\text { hemodialysis } \\
\text { patients }\end{array}$ & $\begin{array}{l}\text { (1) A methodological } \\
\text { study of the } \\
\text { construction and } \\
\text { validation of an } \\
\text { instrument for } \\
\text { measuring FHL; (2) } \\
\text { to assess the level } \\
\text { of health literacy } \\
\text { of the hemodialysis } \\
\text { population in Taiwan } \\
\text { using the developed } \\
\text { tool. }\end{array}$ & $\begin{array}{l}\text { The sample consisted } \\
\text { of individuals older } \\
\text { than 18, and was } \\
\text { not specific to the } \\
\text { elderly population. } \\
\text { The knowledge of } \\
\text { hemodialysis patients } \\
\text { about daily practices } \\
\text { is satisfactory, while } \\
\text { critical health literacy } \\
\text { is weak. }\end{array}$ \\
\hline
\end{tabular}


Continuation of Chart 1

\begin{tabular}{|c|c|c|c|c|}
\hline $\begin{array}{l}\text { Title, authors, country } \\
\text { and year of publication }\end{array}$ & $\begin{array}{l}\text { Method/level of } \\
\text { evidence }\end{array}$ & Instrument used & Objective & Results \\
\hline $\begin{array}{l}\text { A Cross-Sectional } \\
\text { Comparison of Health } \\
\text { Literacy Deficits Among } \\
\text { Patients With Chronic } \\
\text { Kidney Disease. Kelly } \\
\text { Lambert, Judy Mullan, } \\
\text { Kylie Mansfield \& } \\
\text { Maureen Lonergan. } \\
\text { Autralia,2015. }\end{array}$ & $\begin{array}{l}\text { Descriptive cross- } \\
\text { sectional / VI }\end{array}$ & $\begin{array}{l}\text { Health Literacy } \\
\text { Management Scale } \\
\text { (HeLMS) }\end{array}$ & $\begin{array}{l}\text { To investigate the } \\
\text { types and extent } \\
\text { of health literacy } \\
\text { deficits of chronic } \\
\text { kidney patients } \\
\text { and to identify } \\
\text { associations between } \\
\text { the characteristics of } \\
\text { the patients and FHL } \\
\text { domains measured by } \\
\text { HeLMS. }\end{array}$ & $\begin{array}{l}\text { The mean age of the } \\
\text { participants was } 64.1 \\
\text { years, and while the } \\
\text { elderly were included, } \\
\text { the application of the } \\
\text { test was not limited to } \\
\text { this public. This study } \\
\text { identified inadequate } \\
\text { health literacy - } \\
\text { especially in the areas } \\
\text { related to health care } \\
\text { needs, understanding } \\
\text { of health information, } \\
\text { social support, and } \\
\text { socioeconomic factors. }\end{array}$ \\
\hline $\begin{array}{l}\text { Relationship between } \\
\text { Health Literacy and } \\
\text { Kidney Function. } \\
\text { Radhika Devraj, } \\
\text { Matthew Borrego, A } \\
\text { Mary Vilay, Elisa J. } \\
\text { Gordon, Junvie Pailden, } \\
\text { Bruce Horowitz. } \\
\text { USA, } 2015 .\end{array}$ & $\begin{array}{l}\text { Observational } \\
\text { Cross-sectional/ } \\
\text { VI }\end{array}$ & $\begin{array}{l}\text { Newest Vital Sign } \\
\text { (NVS) }\end{array}$ & $\begin{array}{l}\text { To evaluate the } \\
\text { relationship between } \\
\text { FHL and estimated } \\
\text { glomerular filtration } \\
\text { rate. }\end{array}$ & $\begin{array}{l}\text { The age of the } \\
\text { participants ranged } \\
\text { from } 21 \text { to } 90 \text { years. } \\
\text { The prevalence of } \\
\text { limited FHL was } \\
63 \% \text {, with a small but } \\
\text { significant association } \\
\text { between FHL and the } \\
\text { estimated glomerular } \\
\text { filtration rate. }\end{array}$ \\
\hline $\begin{array}{l}\text { Evaluation of a single- } \\
\text { item screening question } \\
\text { to detect limited health } \\
\text { literacy in peritoneal } \\
\text { dialysis patients. Deepika } \\
\text { Jain, HeenaSheth, } \\
\text { Filitsa H. Bender, } \\
\text { Steven D. Weisbord, } \\
\text { Jamie A. Green } \\
\text { USA, 2014. }\end{array}$ & Cohort/ IV & $\begin{array}{l}\text { Rapid Estimate } \\
\text { of Adult Literacy } \\
\text { in Medicine } \\
\text { (REALM) }\end{array}$ & $\begin{array}{l}\text { To evaluate the health } \\
\text { literacy of } 31 \text { patients } \\
\text { in peritoneal dialysis. }\end{array}$ & $\begin{array}{l}\text { Age ranged from } \\
21-79 \text { years, and the } \\
\text { prevalence of limited } \\
\text { health literacy was } \\
16 \% .\end{array}$ \\
\hline $\begin{array}{l}\text { Limited health literacy } \\
\text { is associated with low } \\
\text { glomerular filtration } \\
\text { in the Chronic Renal } \\
\text { Insufficiency Cohort } \\
\text { (CRIC) study. Ana } \\
\text { C. Ricardo et al. } \\
\text { USA, } 2014 \text {. }\end{array}$ & Cohort/ IV & $\begin{array}{l}\text { Short Test of } \\
\text { Health Literacy } \\
\text { in Adults } \\
\text { (STOFHLA) }\end{array}$ & $\begin{array}{l}\text { Assess the } \\
\text { associations between } \\
\text { limited health literacy } \\
\text { with renal function } \\
\text { and risk factors for } \\
\text { cardiovascular disease. }\end{array}$ & $\begin{array}{l}\text { Age ranged from } \\
21-74 \text { years and those } \\
\text { with limited FHL } \\
\text { were more likely to be } \\
\text { older than participants } \\
\text { with adequate health } \\
\text { literacy. }\end{array}$ \\
\hline $\begin{array}{l}\text { Assessing health } \\
\text { literacy in renal failure } \\
\text { and kidney transplant } \\
\text { patients. Wendy } \\
\text { Escobedo, Penny } \\
\text { Weismuller. USA, } 2013 .\end{array}$ & $\begin{array}{l}\text { Cross-sectional/ } \\
\text { VI }\end{array}$ & $\begin{array}{l}\text { Newest Vital Sign } \\
\text { (NVS) }\end{array}$ & $\begin{array}{l}\text { To identify the level } \\
\text { of health literacy of } \\
\text { patients treated at a } \\
\text { suburban transplant } \\
\text { center using the NVS } \\
\text { tool. }\end{array}$ & $\begin{array}{l}\text { The age range of the } \\
\text { participants was } 21 \\
\text { to } 73 \text { years. Of the } 44 \\
\text { participants, } 18(41 \%) \\
\text { had scores indicating } \\
\text { the probability of } \\
\text { limited health literacy. }\end{array}$ \\
\hline
\end{tabular}


Continuation of Chart 1

\begin{tabular}{|c|c|c|c|c|}
\hline $\begin{array}{l}\text { Title, authors, country } \\
\text { and year of publication }\end{array}$ & $\begin{array}{l}\text { Method/level of } \\
\text { evidence }\end{array}$ & Instrument used & Objective & Results \\
\hline $\begin{array}{l}\text { Communicative and } \\
\text { critical health literacy, } \\
\text { and self-management } \\
\text { behaviors in end-stage } \\
\text { renal disease patients } \\
\text { with diabetes on } \\
\text { hemodialysis. } \\
\text { Alden Yuanhong Lai, } \\
\text { Hirono Ishikawa, } \\
\text { Takahiro Kiuchi, } \\
\text { NandakumarMooppil, } \\
\text { KonstadinaGriva } \\
\text { Singapore, 2013. }\end{array}$ & $\begin{array}{l}\text { Randomized } \\
\text { controlled / II }\end{array}$ & $\begin{array}{l}\text { Functional, } \\
\text { Communicative } \\
\text { and Critical Health } \\
\text { Literacy (FCCHL) }\end{array}$ & $\begin{array}{l}\text { To explore functional, } \\
\text { communicative and } \\
\text { critical health literacy } \\
\text { among patients with } \\
\text { CKD with diabetes } \\
\text { and to examine their } \\
\text { specific relationships } \\
\text { with self-management } \\
\text { behaviors. }\end{array}$ & $\begin{array}{l}\text { The age of the } \\
\text { participants was } 78 \\
\text { years. Self-management } \\
\text { in patients with } \\
\text { CKD with diabetes } \\
\text { was associated with } \\
\text { communicative and } \\
\text { critical FHL, but not } \\
\text { functional FHL. }\end{array}$ \\
\hline $\begin{array}{l}\text { Health literacy associated } \\
\text { with blood pressure but } \\
\text { not other cardiovascular } \\
\text { disease risk factors } \\
\text { among dialysis patients } \\
\text { Gbemisola A. Adeseun, } \\
\text { Christine C. Bonney and } \\
\text { Sylvia E. Rosas USA, } \\
2012 \text {. }\end{array}$ & $\begin{array}{l}\text { Cross-sectional/ } \\
\text { VI }\end{array}$ & $\begin{array}{l}\text { Short Test of } \\
\text { Health Literacy } \\
\text { in Adults } \\
\text { (STOFHLA) }\end{array}$ & $\begin{array}{l}\text { To examine the } \\
\text { relationship between } \\
\text { literacy in health and } \\
\text { cardiovascular risk } \\
\text { factors }\end{array}$ & $\begin{array}{l}\text { The mean age was } \\
51.6 \text { years }( \pm 10.3 \text { for } \\
\text { inadequate FHL and } \\
\pm 13.2 \text { for participants } \\
\text { with adequate FHL). } \\
\text { The majority of } \\
\text { participants had } \\
\text { adequate health literacy } \\
\text { while } 21 \% \text { had limited } \\
\text { health literacy. }\end{array}$ \\
\hline $\begin{array}{l}\text { Prevalence and } \\
\text { demographic and } \\
\text { clinical associations } \\
\text { of health literacy in } \\
\text { patients on maintenance } \\
\text { hemodialysis. Jamie } \\
\text { A. Green et al. } \\
\text { USA, 2011. }\end{array}$ & Cross-sectional & $\begin{array}{l}\text { Rapid Estimate } \\
\text { of Adult Literacy } \\
\text { in Medicine } \\
\text { (REALM) }\end{array}$ & $\begin{array}{l}\text { To analyze the } \\
\text { prevalence of } \\
\text { limited FHL and } \\
\text { the association with } \\
\text { demographic and } \\
\text { clinical characteristics } \\
\text { in patients undergoing } \\
\text { maintenance } \\
\text { hemodialysis. }\end{array}$ & $\begin{array}{l}\text { The median age was } \\
64 \text { years }(56-73) \text {. } \\
\text { Of the } 260 \text { patients } \\
\text { who completed } \\
\text { the REALM, } 41 \\
\text { demonstrated limited } \\
\text { health knowledge. }\end{array}$ \\
\hline $\begin{array}{l}\text { Development and results } \\
\text { of a kidney disease } \\
\text { knowledge survey given } \\
\text { to patients with CKD. } \\
\text { Julie A. Wright, Kenneth } \\
\text { A. Wallston, Tom A. } \\
\text { Elasy, T. Alp Ikizler and } \\
\text { Kerri L. Cavanaugh. } \\
\text { USA, 2011. }\end{array}$ & $\begin{array}{l}\text { Cross-sectional/ } \\
\text { VI }\end{array}$ & $\begin{array}{l}\text { Rapid Estimate } \\
\text { of Adult Literacy } \\
\text { in Medicine } \\
\text { (REALM) }\end{array}$ & $\begin{array}{l}\text { To develop valid } \\
\text { and reliable research } \\
\text { to measure the } \\
\text { specific knowledge } \\
\text { of individuals on } \\
\text { conservative treatment } \\
\text { of renal disease } \\
\text { and to describe } \\
\text { the characteristics } \\
\text { associated with low } \\
\text { knowledge. }\end{array}$ & $\begin{array}{l}\text { The median age of } \\
\text { participants was } 58 \\
\text { (percentile } 25-75 \text {, } \\
\text { 46-68) years. Limited } \\
\text { literacy was } 77 \% \text {. }\end{array}$ \\
\hline $\begin{array}{l}\text { Low health literacy } \\
\text { associates with increased } \\
\text { mortality in ESRD. } \\
\text { Kerri L. Cavanaugh. } \\
\text { USA, } 2010 .\end{array}$ & $\begin{array}{l}\text { Prospective } \\
\text { cohort }\end{array}$ & $\begin{array}{l}\text { Rapid Estimate } \\
\text { of Adult Literacy } \\
\text { in Medicine } \\
\text { (REALM) }\end{array}$ & $\begin{array}{l}\text { To describe the } \\
\text { prevalence of limited } \\
\text { health literacy and } \\
\text { its association with } \\
\text { mortality risk in } \\
\text { hemodialysis patients }\end{array}$ & $\begin{array}{l}\text { The median age was } \\
62.0 \text { years. Compared } \\
\text { with adequate } \\
\text { literacy, limited } \\
\text { health knowledge was } \\
\text { associated with an } \\
\text { increased risk of death. }\end{array}$ \\
\hline
\end{tabular}


Continuation of Chart

\begin{tabular}{|l|l|l|l|l|}
\hline $\begin{array}{l}\text { Title, authors, country } \\
\text { and year of publication }\end{array}$ & $\begin{array}{l}\text { Method/level of } \\
\text { evidence }\end{array}$ & Instrument used & Objective & Results \\
\hline $\begin{array}{l}\text { Perceived susceptibility } \\
\text { to chronic kidney } \\
\text { disease among high-risk } \\
\text { patients seen in primary } \\
\text { care practices L. Ebony } \\
\begin{array}{l}\text { Boulware, Kathryn A. } \\
\text { Carson, Misty U. Troll, } \\
\text { Neil R. Powe and Lisa A. } \\
\text { Coope. USA, 2009. }\end{array}\end{array}$ & $\begin{array}{l}\text { Randomized } \\
\text { controlled/II }\end{array}$ & $\begin{array}{l}\text { Rapid Estimate } \\
\text { of Adult Literacy } \\
\text { in Medicine } \\
\text { (REALM) }\end{array}$ & $\begin{array}{l}\text { To assess the } \\
\text { perception of risk and } \\
\text { concern regarding } \\
\text { the development or } \\
\text { progression of CKD } \\
\text { among high-risk } \\
\text { patients receiving } \\
\text { primary care. }\end{array}$ & $\begin{array}{l}\text { Participants had } \\
\text { diverse demographic } \\
\text { characteristics, with } \\
\text { a high proportion of } \\
\text { participants aged } 60 \\
\text { years or over, who } \\
\text { were female and } \\
\text { African American or } \\
\text { black. Many patients } \\
\text { were at high risk for } \\
\text { the development or } \\
\text { progression of CKD. }\end{array}$ \\
\hline $\begin{array}{l}\text { Health literacy and access } \\
\text { to kidney transplantation. } \\
\text { Vanessa Grubbs, Steven } \\
\text { E. Gregorich, } \\
\text { Eliseo J. Perez-Stable, } \\
\text { and Chi-yuan Hsu. } \\
\text { USA, 2009. }\end{array}$ & Cross-sectional & $\begin{array}{l}\text { Test of Health } \\
\text { Literacy in Adults } \\
\text { (TOFHLA) }\end{array}$ & $\begin{array}{l}\text { Examining health } \\
\text { literacy in patients } \\
\text { with end-stage kidney } \\
\text { disease }\end{array}$ & $\begin{array}{l}\text { Age ranged from 18 to } \\
75 \text { years. About one- } \\
\text { third (32.3\%) of the } \\
\text { participants had poor } \\
\text { health literacy. }\end{array}$ \\
\hline
\end{tabular}

*FHL: functional health literacy

A total of 14 articles had the objective of researching the measurement of literacy levels in the context of CKD, while one sought to validate a FHL instrument. In the studies analyzed, the elderly were included in the analyzes, but no specific instrument was identified for this public, and the research was performed without limiting age. However, the available tests were found to be adequate, with satisfactory results.

Seven different health literacy assessment instruments were identified in the 15 articles analyzed: the TOFHLA, REALM, SILS, TAIWAN SCALE, NVS, HELMS AND FCCHL. The TOFHLA (Test of Functional Health Literacy In Adults) and REALM (Rapid Estimate of Adult Literacy in Medicine) were the most commonly used instruments. The REALM was used in five articles (33.3\%), all in the USA, and the TOFHLA was used in four articles (26.6\%), three in the USA and one in Brazil. The NVS was used in two articles (13.3\%), both in the USA. The other instruments used were the SILS, the Taiwanese scale, the HELMS and the FCCHL, all of which were used in one article each (6.7\%), in the UK, Taiwan, Australia and Singapore, respectively. All the instruments used addressed the patient in the context of CKD, from the pre-dialytic phase to transplantation, in addition to peritoneal dialysis and comparison with renal function, evaluating the association between the disease and FHL.

\section{DISCUSSION}

The present review identified the instruments used to evaluate FHL among elderly patients with CKD. OF these, the REALM and TOFHLA stood out as choices for application by health professionals among this clientele. The studies were mostly carried out in the USA, with a cross-sectional design, indicating the incipience of Brazilian studies.

The studies showed that the knowledge of CKD of patients is insufficient, a fact possibly related to age and cognitive impairment ${ }^{10}$. They do not understand the permanent nature of the disease, believing that treatment will lead to the cure of their kidney problems. They also do not know that conservative treatment is intended to reduce or maintain renal damage without progression, to postpone the need for dialysis replacement therapy ${ }^{15}$. 
Identifying patients with inadequate $\mathrm{FHL}$ is not a simple task. Studies show that, in the context of health, individuals have considerable difficulty in reading texts typical of this situation. This limitation, associated with the fact that health professionals do not understand the literacy level of their patients, resulting in the use of an extremely specialized language, favors the occurrence of negative clinical outcomes $^{16}$. In the USA, the National Working Group on Literacy and Health has warned of the inability of health professionals to recognize patients with inadequate FHL, and research has shown that physicians have difficulty detecting inadequate FHL levels in their patients ${ }^{17}$.

Among the instruments used to measure FHL in the elderly, Carthery-Goulart et al. ${ }^{18}$ state that the Short Test of Health Literacy in Adults (S-TOFHLA) can be a practical tool for screening individuals with functional illiteracy in the context of health care, focused on the identification of people with a greater need of special care. However, this is the short version of the instrument known as the 1995 Test of Health Literacy in Adults (TOFHLA). The English and Spanish versions of S-TOFHLA have been translated and adapted for use in Brazil, notably the reading comprehension texts, to convey information about the Unified Health System (or SUS). However, its terminology was maintained, and it is worth noting that despite using the STOFHLA acronym, the Brazilian version is abbreviated. Therefore, Brazilian studies ${ }^{9,19,20}$ tend to adopt the B-TOFHLA terminology.

TOFHLA is especially geared towards identifying numeracy and reading comprehension skills. It consists of two subtests: one composed of 17 items, which measures numerical ability, and the other with 50 items, which evaluates reading comprehension. S-TOFHLA has 36 reading comprehension items. The brief version, B-TOFHLA, is made up of the same 36 items as S-TOFHLA and four additional numeracy items. The long version takes up to 22 minutes to administer, the short version lasts 7 minutes and the brief version 12 minutes. In each TOFHLA subtest the questions earn points. In the full version 100 total points are available, 50 of which relate to reading comprehension and 50 to numeracy. The total sum of the scores (numeracy plus reading comprehension) provides the literacy profile of the individual being assessed, which is divided into three levels: Inadequate FHL (0-59 scores); Marginal FHL (60-74 scores); Adequate FHL (75-100 scores $)^{21}$.

Another instrument used was the Rapid Estimate of Adult Literacy in Medicine (REALM), which was developed for use with adults and provides a rapid estimate of the reading level of common medical terms and involves only word recognition and not the understanding of individuals. The test consists of simple words arranged in columns containing terms of one or two syllables and three syllables or more. The instrument is validated in English, Spanish (The Short Assessment of Health Literacy for Spanish speaking Adults-SAHLSA) and Portuguese (The Short Assessment of Health Literacy for Portuguesespeaking Adults-SAHLPA) ${ }^{22}$.

In addition to the TOFHLA and the REALM, the Newest Vital Sign (NVS) scale is a validated instrument for measuring FHL, requiring the respondent to review the nutritional label of one liter of ice cream and orally answer six questions based on the label. A score of four or more indicates adequate literacy, a score of two to three indicates limited literacy and a score of zero to one indicates a high probability of limited literacy ${ }^{23}$.

The Functional, Communicative and Critical Health Scale (FCCHL) was also used to assess FHL levels. This is an instrument developed in relation to the structure of literacy as a separate component of functional, communicative and critical literacy. With five items for each FHL subscale and communicative literacy, and four for critical FHL, this self-reported measure of 14 items was evaluated in a range of one to four (never to many times) for each item. The scores of the items of each subscale were added together and divided by the number of constituent items of the subscale, resulting in a score (the theoretical variation for each domain was one to four). Higher scores indicate higher levels of FHL ${ }^{24}$.

The literacy scale created in Taiwan was divided into assessment of health literacy and demographic information. There are a total of 52 items in the questionnaire, with 26 items in each section. The health literacy section was adapted from the Nutbeam 
model and incorporated its three fundamental constructs: critical literacy in health, health literacy and functional literacy in health. The health literacy section includes seven subconstructs: functional literacy (five items), communicative literacy (four items), interactive literacy (three items), critical literacy (three items), basic health knowledge (four items), advanced health knowledge (five items) and patient safety (two items). A point is earned each time the respondents select the correct answer from the four multiple choice options; no points are awarded if the response is incorrect or no response is provided. The maximum total score is 26 and the minimum, zero. While other health literacy tools assess the ability to spell and pronounce medical terminology, this instrument placed more emphasis on assessing whether patients had health knowledge specific for dialysis to maintain their well-being. This means that patients should be more familiar with these problems and be able to make the right choices ${ }^{25}$.

The Health Literacy Management Scale (HELMS) is a multidimensional health literacy assessment tool, developed and validated in Australia to identify the elements of FHL. The HELMS consists of 29 questions classified subjectively, and divided into eight domains. Domains two and five to eight include individual skills while the other three domains assess broader aspects such as attitudes, social support, and socioeconomic factors that can impact FHL. Scores less than or equal to four suggest inadequate $\mathrm{FHL}^{26}$.

Another test used is the Single-Item Literacy Screener (SILS), which verifies health literacy using the following question: How often do you need someone to help you when you read instructions, pamphlets, or other written materials from your doctor or pharmacy? The options are: 1-never, 2-rarely, 3-sometimes, 4-often, and 5-always. The answers sometimes, often and always represent a limited level of health literacy ${ }^{27}$.

The use of different instruments in the articles in this review partially limits the comparison between the studies due to the different realities of the elderly in the countries in which the research was carried out.
A scarcity in literature of studies that evaluate the relationship between functional literacy in health and CKD and which are specific for the elderly was noted.

It should therefore be emphasized that measures aimed at raising FHL levels should focus both on improving individual competencies and on the role of humanized health services, which should improve their written and oral communications to meet the needs (and skills) of the elderly.

\section{CONCLUSION}

The present study identified instruments that evaluate FHL in elderly persons with CKD, verifying their suitability for this public. Among these, the REALM and TOFHLA instruments stood out. Most studies were conducted in the USA, with cross-sectional designs predominating. The elderly were included in the FHL tests, although no specific instruments were found to evaluate this population. The construction and/or adaptation of new instruments considering the specificities of this age group is suggested.

The identification of the instruments addressed in this study can facilitate the development of specific interventions to improve FHL, as well as making available to the population and health professionals instruments that evaluate literacy in the elderly, thus resulting in the improvement of care. It is therefore necessary to develop communicative processes between health teams and health service users, producing strategies that strengthen FHL skills, recognizing the needs of the elderly.

In addition to confirming the importance of assessing the level of FHL in the overall care of the elderly with chronic kidney disease, it is hoped that the results found contribute to increasing the application of such assessments. Therefore, it is essential that other studies with diversified initiatives are carried out to alter the planning of actions and behaviors in health, aimed at achieving better results in the production of care for this population. 


\section{REFERENCES}

1. World Health Organization. Health literacy. Solid Facts [Internet]. Geneva: WHO; 2013 [acesso em 26 mar. 2019]. Disponível em: http://publichealthwell.ie/ node/ 534072

2. Santos MIPO, Portella MR, Scortegagna HM, dos Santos PCS. Letramento funcional em saúde na perspectiva da Enfermagem Gerontológica: revisão integrativa da literatura. Rev Bras Geriatr Gerontol [Internet]. 2015 [acesso em 26 mar. 2019];18(3):651-64. Disponível em: http://www. scielo.br/scielo.php?script=sci_arttext\&pid=S180998232015000300651\&lng=en

3. Martins AMEBL, Almeida ER, Oliveira CC, Oliveira RRCN, Pelino JEP, Santos ASF, et al . Alfabetização em saúde bucal: uma revisão da literatura. Rev Assoc Paul Cir Dent [Internet]. 2015 [acesso em 26 mar. 2019];69(4):328-39. Disponível em: http:// revodonto.bvsalud.org/scielo.php?script $=$ sci_ arttext\&pid=S0004-52762015000300002\&lng=pt

4. Souza Filho PP, Massi GA. Letramento de idosos brasileiros acima de 65 anos. Distúrb Comun. 2014;26(2):267-76.

5. Serrão C, Veiga S, Vieira IM. Literacia em saúde: resultados obtidos a partir de uma amostra de pessoas idosas portuguesas. Rev Port Enferm Saúde Mental. 2015;(Esp 2):33-8.

6. Devraj R, Borrego M, Vilay AM, Gordon EJ, Pailden J, Horowitz B. Relationship between health literacy and kidney function. Nephrology. 2015;20(5):360-7.

7. Bastos MG, Abreu PF. Doença renal crônica em pacientes idosos. Braz J Nephrol. 2009;31(1 Suppl 1):59-65.

8. Silva ST, Ribeiro RCL, Barbosa RCO, Mitre CRM. Capacidade cognitiva de indivíduos com doença renal crônica: relação com características demográficas e clínicas. J Bras Nefrol [Internet]. 2014 [acesso em 26 mar. 2019];36(2):163-70. Disponível em: http://www. scielo.br/scielo.php?script $=$ sci_arttext\&pid=S010128002014000200163\&lng=en

9. Matta SM, Moreira JM, Kummer AM, Barboza IG, Teixeira AL, Silva ACS Alterações cognitivas na doença renal crônica: uma atualização. J Bras Nefrol. 2014;36(2):241-5.

10. Moraes KL. Conhecimento e letramento funcional em saúde de pacientes em tratamento pré-dialítico de um hospital de ensino [dissertação]. Goiânia: Universidade Federal de Goiás; 2014.

11. Polit DF, Beck CT, Hungler BP. Fundamentos de pesquisa em enfermagem: métodos, avaliação e utilização. $6^{a}$ ed. Porto Alegre: Artmed; 2006.
12. Polit DF, Beck CT, Hungler BP. Fundamentos de pesquisa em enfermagem: avaliação de evidências para prática em enfermagem. $9^{a}$ ed. Porto Alegre: Artmed; 2018.

13. Milton Keynes Primary Care Trust. Critical Appraisal Skills Programme. [no place]: [unknown publisher]; 2002.

14. Stillwell S, Melnyk BM, Fineout-Overholt E, Williamson K. Evidence-based practice: step by step. Am J Nurs. 2010;110(5):41-7.

15. Santos RLG, Oliveira DRF, Nunes MGS, Barbosa RMP, Gouveia VA. Avaliação do conhecimento do paciente renal crônico em tratamento conservador sobre modalidades dialíticas. Rev Enferm UFPE online. 2015;9(2):651-60.

16. Santos LTM, Mansur HN, de Souza Paiva TFP, Colugnati FAB, Bastos MG. Health literacy: importance of assessment in nephrology. J Bras Nefrol. 2012;34(3):293-302.

17. Williams MV, Davis T, Parker RM, Weiss BD. The role of health literacy in patient-physician communication. Fam Med. 2002;34:383-9.

18. Carthery-Goulart MT, Anghinah R, ArezaFegyweres R, Bahia VS, Brucki SM, Damin A, et al. Performance of a brazilian population on the test of functional health literacy in adults. Rev Saúde Pública. 2009;43(4):631-8.

19. Bezerra JNM, Lessa SRO, do Ó MF, Luz GOA, Borba AKOT. Letramento em saúde dos indivíduos submetidos à terapia dialítica. Texto \& Contexto Enferm [Internet]. 2019 [acesso em 02 maio 2019];28: 1-13. Disponível em: http://www.scielo. br/scielo.php?script $=$ sci_arttext\&pid $=$ S010407072019000100304\&lng=pt

20. Sampaio HAC, Carioca AAF, Sabry MOD, Santos PM, Coelho MAM, Passamai MPB. Letramento em saúde de diabéticos tipo 2: fatores associados e controle glicêmico. Ciênc Saúde Colet. 2019;20(3):865-74.

21. Baker DW, Williams MV, Parker RM, Gazmararian JA, Nurss J. Development of a brief test to measure functional health literacy. Patient Educ Couns. 1999;38(1):33-42.

22. Apolinario D, Braga RC, Magaldi RM, Busse AL, Campora F, Brucki S, et al. Short assessment of health literacy for Portuguese-speaking adults. Rev Saúde Pública. 2012;46(4):702-11.

23. Escobedo W, Weismuller P. Assessing health literacy in renal failure and kidney transplant patients. Prog Transplant. 2013;23(1):47-54. 
24. Lai AY, Ishikawa H, Kiuchi T, Mooppil N, Griva K. Communicative and critical health literacy, and self-management behaviors in end-stage renal disease patients with diabetes on hemodialysis. Patient Educ Couns. 2013;91(2):221-7.

25. Chung-liang S, Tuan-hsun C, Dana A J, Chiunghsuan C. Development of a health literacy questionnaire for taiwanese hemodialysis patients. BMC Nephrol. 2016;17:1-12.
26. Lambert K, Mullan J, Mansfield K, Lonergan M. A cross-sectional comparison of health literacy deficits among patients with chronic kidney disease. J Health Comun. 2015;20:16-23.

27. Taylor DM, Bradley JA, Bradley C, Draper H, Johnson R, Metcalfe W, et al. Limited health literacy in advanced kidney disease. Kidney Int. 2016;90(3):685-95. 